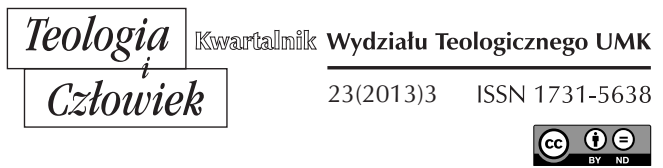

KS. JOSÉ RAMÓN VILLAR*

PAMPELUNA

\title{
„PRAEPARATIO EVANGELICA", CZYLI O PROPEDEUTYCE WIARY WE WSPÓłCZESNYCH CZASACH
}

DOI: http://dx.doi.org/10.12775/TiCz.2013.033

\section{WPROWADZENIE}

Niedawne obrady synodu biskupów poświęconego nowej ewangelizacji stanowią pilne wezwanie do ożywienia działań ewangelizacyjnych w naszych czasach. Nie chodzi o koniunkturalne i przejściowe wezwanie. Ewangelizacja jest zadaniem permanentnym, bo Kościół jest isotowo misyjny.

Chrześcijańskie głoszenie musi uwzględniać okoliczności, w których znajdują się odbiorcy kierujący się przekazem, „aby dać konsekwentne świadectwo - mówi Benedykt XVI - w innych warunkach historycznych niż w przeszłości" ${ }^{1}$. Zwłaszcza w świecie zachodnim pojawiły się nowe uwarunkowania społeczne i kulturowe, odmienne od poprzednich. Dlatego warto rozszyfrować nowe wyzwania, przed którymi staje przekaz wiary w naszych czasach.

* Ks. prof. dr José Ramón Villar - profesor teologii dogmatycznej, specjalizujący się w zagadnieniach eklezjologicznych i ekumenicznych; kierownik Zakładu Teologii Systematycznej na Wydziale Teologii Uniwersytetu Nawarry w Pampelunie.

${ }^{1}$ Motu proprio, Porta fidei, n. 4. 
Nie jest łatwą sprawą dokonać analizy sytuacji tak skomplikowanej jak obecna. Dlatego nie jest również łatwo wyznaczyć jeden jedyny program działań ewangelizacyjnych, który odniesie się do wszystkich problemów. Z jednej strony dostrzegamy w naszym społeczeństwie wiele zjawisk pozytywnych. Na przykład istnieje silne przekonanie co do godności osób, obrony praw człowieka, potępienia przemocy, czy większego szacunku wobec przyrody, pragnienie osiągnięcia wspólnej przestrzeni opartej na podstawowych wartościach etycznych etc. Ale obecność tych i innych cech pozytywnych nie oznacza ignorowania negatywnych cech kultury, w której współistnieją różne kosmowizje ideologiczne wzajemnie się wykluczające. Żyjemy w epoce fragmentaryzacji i utraty orientacji. Ale to wszystko nie ma prowadzić do podnoszenia lamentu czy skłaniać ludzi wierzących do pasywności, lecz przeciwnie, powinno stać się bodźcem do podjęcia nowej ewangelizacji.

Nie jest możliwe w krótkim artykule podjęcie tego tematu w całej jego rozciągłości. Dlatego chciałbym się skupić tylko na jednym aspekcie. Moim punktem wyjścia będzie stwierdzenie papieża Benedykta XVI zapisane w motu proprio Porta fidei ogłaszającym Rok Wiary w pkt. 2. Ojciec Święty stwierdza, że „Podczas gdy w przeszłości można było rozpoznać jednorodną tkankę kulturową, powszechnie akceptowaną w swym odniesieniu do treści wiary i inspirowanych nią wartości, to obecnie wydaje się, że w znacznej części społeczeństwa już tak nie jest, z powodu głębokiego kryzysu wiary, który dotknął wielu ludzi.

\section{KONIECZNOŚĆ „PRZYGOTOWANIA DO EWANGELII”}

Papież mówi o "głębokim kryzysie wiary", który jest związany z załamaniem się ,"jednorodnej tkanki kulturowej", która podtrzymywała postawę religijną większości Europejczyków. W szczególności kryzys wiary wiąże się z osłabieniem niektórych założeń kulturowych, które są niczym szkielet, na którym może zakorzenić się wiara chrześcijańska. Wiara musi oprzeć się na fundamentalnych przekonaniach o konstytutywnym otwarciu bytu ludzkiego na Boga, na autentycznej racjonalności, na możliwości dotarcia do prawdy i osiągnięcia pewności, na dobru i złu jako kategoriach poprzedzających zgodę społeczeną, na zagadnieniu sensu egzystencji ludzkiej i istnienia Boga. Gdy te założenia znikają, wydaje się czymś niezwykle trudnym przyjęcie orędzia chrześcijańskiego. 
Dlatego jest konieczne naprawienie założeń, które umożliwiają przyjęcie wiary. Stąd nowa ewangelizacja wymaga, poza żywym świadectwem wspólnoty chrześcijańskiej, również pewnej praeparatio evangelii, która uwzględni okoliczności kulturowe, zdecydowanie różne od tych, z którymi spotkały się pierwsze pokolenia chrześcian w czasach pierwszej ewangelizacji ${ }^{2}$.

W tradycji chrześcijańskiej wyrażenie „przygotowanie do Ewangelii" odnosiło się do tych prawd o charakterze racjonalnym, które służą za praeambula fidei, założeń, które ułatwiają drogę do wiary i które pozwalają na dialog z kulturami i filozofią w każdej epoce ${ }^{3}$. Wydaje się niezwykle potrzebne takie "przygotowanie” również w naszych czasach. Jedna z „propozycji” przekazanych Ojcu Świętemu przez ostatni synod poświęcony nowej ewangelizacji zwraca uwagę właśnie na tę potrzebę. Pod tytułem "preambuły wiary i teologia wiarygodności” (Propozycja nr 17), ojcowie synodalni stwierdzali:

W obecnym kontekście kultury globalnej istnieje wiele wątpliwości i przeszkód, które przyczyniają się do rozszerzającego się sceptycyzmu i wprowadzają nowe paradygmaty do myślenia i życia. W obliczu nowej ewangelizacji wydaje się żywotnie ważne podkreślenie roli preambut wiary. Nie tylko jest konieczne wykazanie, że wiara nie sprzeciwia się rozumowi, lecz również, że wiele prawd i zagadnień stanowi część poprawnej antropologii, która jest oświecana przez rozum naturalny. Wśród nich znajduje się wartość „prawa naturalnego” i jego konsekwencji dla społeczności ludzkiej. Pojęcia takie jak „prawo naturalne” czy „natura ludzka" są podatne na dowody racjonalne zarówno na poziomie akademickim, jak i popularnym. Podobne zadania i rozwój intelektualny pomógłby dialogowi między wiernymi chrześcijańskimi i osobami dobrej woli, otwierając drzwi do uznania istnienia Boga Stworzyciela i orędzia o Jezusie Chrystusie, Zbawicielu. Ojcowie synodalni proszą teologów, aby rozwijali nową apologetykę myślenia chrześcijańskiego, to znaczy, teologię wiarygodności odpowiednią dla Nowej Ewangelizacji.

Ojcowie synodalni proszą o apologię wiary, która ma ukształtować ducha do przyjęcia Ewangelii, tak jak to czyniły w swoim czasie pierw-

2 Por. Cl. Geffré, Les enjeux de la culture contemporaine pour la foi chrétienne, "Laval théologique et philosophique" 53 (1996), s. 565-581.

${ }^{3}$ Por. G. Cottier, Itinéraire vers la foi: la "Praeparatio evangelica" et les "Praeambula fidei", "Nova et vetera" (1999), s. 51-59. 
sze pokolenia chrześcijan. Ale ta apologetyka ma być nowa, ponieważ ewangelizacja natrafia dziś na Zachodzie na proces sekularyzacji, który stawia się ogólnie w kontrze wobec religii, a w szczególności przeciw wierze chrześcijańskiej; jest to zjawisko historycznie nowe i jedynie możliwe w społeczności postchrześcijańskiej. Bez wątpienia, zawsze istniała niewiara, a nawet wrogość wobec wiary chrześcijańskiej, promowana przez pewne kręgi intelektualne i polityczne. Ale nowość obecnej sytuacji polega na jego bezkrytycznym przyjęciu w szerokich sferach społeczeństw zachodnich.

W ten sposób propedeutyka wiary musi zetrzeć się głównie z współczesnymi uprzedzeniami wobec religii. Niewiara w swych różnych formach (ateizm, agnostycyzym, indyferetyzm) to najmocniejsze wyzwanie, z którym musi się zmierzyć nowa ewangelizacja.

\section{NIEWIARA I JEJ KORZENIE}

Jak wiadomo geneza niewiary sięga korzeniami klasycznego ateizmu z XIX wieku

Jednym z czynników, który w tym czasie pomógł ateizmowi, był spektakularny postęp naukowy i techniczny na polu nauk naturalnych. Informacje, którą dostarczały nowoczesne badania naukowe wydawało się, że biorą w nawias (kwestionują) refleksję metafizyczną i teologiczą. Dokładne poznanie faktów i praw naturalnych poprzez obserwację empiryczną wydawało się niektórym jedyną drogą do odkrycia prawd rzeczy. W konsekwencji, ta postawa intelektualna - reprezentowana na przykład przez Augusta Comte'a - radykalnie wzbraniała przyjęcia prawdy religijnej nieweryfikowalnej. Wszelkie twierdzenia transcendentne były skazane na brak znaczenia: „Każde twierdzenie, które ostatecznie nie jest sprowadzalne do prostego wyrażenia poszczególnego czy ogólnego faktu, nie może zaofiarować żadnego znaczenia realnego ani inteligibilnego" ${ }^{\prime 5}$.

Z tym „pozytywizmem naukowym” połączył się inny nurt promujący ateizm, a którym był humanizm areligijny, wedle którego trzeba

${ }^{4} \mathrm{O}$ ateizmie i jego wariantach, por. A. González Montes, Negación y deformaciones de la fe: agnosticismo, ateísmo e indiferentismo, w: tenże, Teología fundamental de la revelación $y$ de la fe, BAC, Madrid 2012, s. 503-555.

5 A. Comte, Cours de Philosophie Positive, w: tenże, Ouvres, Paris 1968-1970, VI, s. 647 . 
zanegować Boga, aby afirmować człowieka jako jedynego odpowiedzialnego za samego siebie i losy świata. Wiara w Boga byłaby zwykłą wyobrażeniową projekcją idei i atrybutów człowieka. Trzeba więc uwolnić człowieka z tej mrzonki i zwrócić go przeznaczeniu jedynie wewnątrzświatowemu, aby ludzkość mogła zwycięsko maszerować ku nieograniczonemu postępowi. Zarówno pozytywizm naukowy, jak i humanizm areligijny były optymistyczne odnośnie do człowieka i jego postępu. „Neguję - mówił Feuerbach - jedynie, aby afirmować; neguję fantazję religii jedynie po to, aby afirmować realny byt człowieka" ${ }^{6}$.

Nietzsche stwierdzi zmierzch Boga chrześcijańskiego w ateizmie swojej epoki. „Największa nowość tego czasu, że Bóg umarł, że wiara w chrześcijańskiego Boga niesłychanie osłabła, zaczyna rzucać się pierwszym cieniem nad Europą" 7. Ale Nietzsche doda tragiczny charakter tej nieobecności Boga, która prowadzi do absurdu i utraty sensu wszechświata i człowieka: "całkowity charakter świata - powie Nietzsche - to chaos na całą wieczność [...], brak porządku, artykulacji formy, piękna, mądrości"8. W ten sposób negacji Boga już nie towarzyszy optymistyczna afirmacja człowieka, lecz nihilizm zbudowany na podejrzeniu, że wszystko jest na próżno. „Nie istnieje cel ani odpowiedź na pytanie o po co [...] Nihilizm radykalny [...] Przekonanie o całkowitej niespójności egzystencji”’.

Takie rozumowania pozostawiły ślad w wielu aspektach naszej kultury. To prawda, że nihilizm stracił swój pierwotny, dramatyczny charakter i został zredukowany do hedonistycznej obojętności i rozrywkowego carpe diem: korzystania i cieszenia się życiem, bez stawiania sobie pytań nierozstrzygalnych. Cały czas pozostaje aktywne uprzedzenie scjentyzmu pozytywistycznego jako jedynego dostępu do rzeczywistości. Ten pozytywizm podtrzymuje i karmi, w sposób niejasny, ale skuteczny, niewiarę wielu osób nam współczesnych.

Dlatego jedno z założeń nowej ewangelizacji będzie polegało na odzyskaniu przekonania o zdolności rozumu ludzkiego do dotarcia do prawdy i pewności na wielorakich drogach poznania empirycznego. Warto zatrzymać się przy tym zagadnieniu.

s. 29.

${ }^{6}$ L. Feuerbach, Sämtliche Werke, W. Bolin, F. Jodl (Hrsg.), VIII, Stuttgart 1959,

${ }^{7}$ F. Nietzsche, Morgenröthe, w Sämtliche Werke. Kritische Studienausgabe (= SW, G. Colli-M. Montinari [red.]) III, s. 85.

${ }^{8}$ F. Nietzsche, Die fröhliche Wissenschaft, w: L. Feuerbach, dz. cyt., III, s. 468.

9 Tamże, s. 518. 


\section{3. „SCJENTYZM” JAKO PODSTAWA NIEWIARY}

Dla mentalności „,scjentystycznej” - tak dalekiej od autentycznej postawy „naukowej” - idee metafizyczne czy religijne są wyrazem witalnych odczuć, ale nie prawdą umocowaną racjonalnie, ponieważ nie są to twierdzenia, które mogą być kontrolowane empirycznie. W konsekwencji są ideami, które nie odpowiadają obiektywnej rzeczywistości, gdyż realne jest tylko to, co może zostać wpisane w całokształt doświadczenia.

Taki był wniosek słynnego Manifestu z 1929 roku neopozytywistów Koła Wiedeńskiego z pierwszej połowy XX wieku. Nie istnieją tajemnice w rzeczywistości, lecz jedynie problemy, które mogą być studiowane i rozwiązane. „Naukowa koncepcja życia” powinna wyzwolić racjonalny dyskurs z pseudomyślenia metafizycznego i teologicznego.

Przez metafizykę rozumieli taki produkt intelektualny, który nie podporządkowuje się doświadczeniu empirycznemu. Jedynie nauka wyzwolona od metafizyki może zaofiarować kosmowizję (Weltanschauung) ścisłą i dokładną w obszarach życia nowoczesnego społeczeństwa: $\mathrm{w}$ gospodarce, w socjologii, $\mathrm{w}$ polityce etc. ${ }^{10}$ Metafizycy, teologowie i mistycy tworzą sztukę, nie naukę; tworzą poezję lub mit, ale nie dyskurs racjonalnie ważny.

W konsekwencji postawa pozytywistyczna, która mogłaby uchodzić za uprawnioną obronę metody naukowej, stała się jednak redukcją ontologiczna: tylko rzeczywistość fizyczna jest realna; a także stała się redukacją epistemologiczna: tylko to, co doświadczane jest racjonalne, i tylko nauka wytwarza prawdę. Wszystko, co poznawane może i powinno być wyjaśniane poprzez prawa fizyki. Jedyną racjonalnością jest racjonalność empiryczna.

Jak wiadomo te idee były już krytykowane przez samych naukowców, jak choćby przez Karla Poppera ${ }^{11}$, Bernarda d'Espagnat ${ }^{12}$ i Ilya Prigogine'a. Ten ostatni stwierdza, że "nauka nie daje nam dostępu do

${ }^{10}$ H. Hahn, O. Neurath, R. Carnap, Wissenschaftliche Weltauffassung - Der Wiener Kreis, przedruk w H. Schleihert (Hrsg.), Logischer Empirismus. Der Wiener Kreis, München 1975, s. 201-222.

${ }^{11}$ Por. K. R. Popper, La lógica de la investigación científica, Madrid 1963.

12 B. D’Espagnat, Ŕ la recherche du Réel. Le regard d'un physicien, Paris 1979; tenże, Un atome de sagesse. Propos d'un physicien sur le réel voilé, Paris 1982. 
tajemnic wszechświata"13. Istnieje rzeczywistość sama w sobie, przestrzeń niezależnej rzeczywistości i niedostępnej dla metody naukowej ${ }^{14}$.

Natomiast aksjomaty pozytywistyczne są jeszcze obecne wśród niektórych naukowców i intelektualistów. Jak stwierdza Skolimowski, „choć wielu już potwierdziło jego śmierć, to pozytywizm, zadziwiające, pozostaje nadal żywy, nie jeśli się go rozważa samego w sobie [...], ale tak jeśli nasycony i rozpuszczony w strukturze nauki, i co jest ważniejsze, w naukowej wizji świata"15.

Obecność pozytywizmu nie została wymazana przez tzw. „słabe myślenie" czy relatywizm postmodernistyczny, który zakwestionował zdolność ludzkiego rozumu do osiągnięcia prawdy, bez zaofiarowania przekonującej alternatywy wobec pozytywizmu.

W ten sposób uczestniczymy w paradoksalnej sytuacji. Z jednej strony nadal pozostaje aktywny „scjentyzm”, który wpływa bezkrytycznie na świat zachodni przez środki przekazu i niemałą literaturę popularną. Z drugiej strony w społeczeństwach rozwiniętych istnieją mocne dawki irracjonaności i łatwowierności (horoskopy i przesądy), i wzrasta liczba astrologów i zwodzących innych.

Widać wyraźnie, że zarówno „scjentyzm” - tak inny, powtórzmy, od autentycznego ducha naukowego - jak irracjonalny przesąd utrudniają przyjęcie orędzia chrześcijańskiego i samej postawy religijnej człowieka. „Przygotowanie do Ewangelii” będzie musiało wziąć na siebie zadanie uratowania ludzkiej racjonalności z tych patologii.

\section{PROPEDEUTYKA WIARY: RATOWANIE RACJONALNOŚCl}

\subsection{RATOWAĆ RACJONALNOŚĆ POZNANIA MĄDROŚCIOWEGO}

Istotnie, zwiastowanie ewangeliczne nie pochodzi z samej racjonalności doświadczalnej. Ale to, co przekracza rozum nie jest w sposób konieczny irracjonalne. Irracjonalność polega raczej na nieprzyjmowaniu innego używania rozumu niż tego w racjonalności doświadczalnej. „Racjonalizm nie jest hipertrofią rozumu, lecz właśnie redukcją, jego

13 I. Prigogine, J. Stengers, La nueva alianza, Madrid 1983, s. 105.

${ }^{14}$ Por. J. Igea, ¿Tiene límites la razón científica? Una respuesta a la luz de la ciencia del siglo XX, w: J. Prades, J. M. Magaz (red.), La Razón Creyente. Actas del Congreso Internacional sobre la Encíclica Fides et Ratio, Madrid 2002, s. 508-515.

${ }^{15}$ H. Skolimowski, Racionalidad evolutiva, Valencia 1979, s. 35. 
samoograniczeniem. Hipertrofia daje o sobie znać jedynie $\mathrm{w}$ decyzji o ograniczeniu własnego pola działania"16.

Rozum jest otwarty na prawdę, która znajduje się poza tym, co empirycznie weryfikowalne. Rozum otwarty na całą rzeczywistość jest czymś bardziej racjonalnym niż jego zredukowanie do tego, co zwyczajnie sprawdzalne ${ }^{17}$. Benedykt XVI zwracał często uwagę na konieczność „poszerzania przestrzeni naszej racjonalności, otwarcia jej na wielkie kwestie prawdy i dobra"18.

Istnieją zatem różne zastosowania rozumu. Poza wiedzą, którą dostarczają dane empiryczne, człowiek zazwyczaj posługuje się ontologią realistyczną poznania zwyczajnego, które nas informuje o tym, co ma dla nas prawdziwe znaczenie, a co z trudnością może zostać udowodnione empirycznie. Nauka opisuje sposób, w jaki zachowuje się świat fizyczno-chemiczny (włączając byt ludzki) w stopniu, w jakim udaje się jej poznać jego mechanizmy. Metoda doświadczalna jest tylko deskryptywna i radykalnie niezdolna do odpowiedzi na transcendentalne pytania o sens świata i człowieka. Nauka odpowiada na pytanie jak rzeczy, ale nie odpowiedania na pytania dlaczego i po co ich istnienia i celowości.

Człowiek to coś więcej niż rozum; racjonalność jest czymś więcej niż prostą racjonalnością doświadczalną; a rzeczywistość to coś więcej niż rzeczywistość fizyczno-chemiczna. Dlatego poznanie empiryczne jest dokładne i przydatne, ale niekompletne i przedostatnie. Musi otworzyć się na poznanie mądrościowe, które odpowie na ostateczne pytania o sens egzystencji ${ }^{19}$. Jak zaznacza Benedykt XVI, chodzi o „poszerzenie naszego pojęcia rozumu i jego stosowania [...], rozum i wiara spotykają się ponownie w nowy sposób, jeśli pokonamy ograniczenia, które sam

${ }^{16}$ J. Sánchez-Cańizares, Razón y fe en la fundación del comprender, "Scripta Theologica" 40 (2008), s. 862.

${ }_{17}$ Por. C. Izquierdo, La racionalidad abierta de Fides et Ratio, w: tenże, Creo, creemos. ¿Qué es la fe?, Madrid 2008, s. 39-45.

${ }^{18}$ Discurso, 19 X 2006.

${ }_{19}$ R. Martínez, L'interazione tra fede e razionalitŕ scientifica, w: G. Maspero, M. Pérez de Laborda, Fede e Ragione: l'incontro e il cammino. In occasione del decimo anniversario dell'enciclica Fides et Ratio, Siena 2011, s.195-222; J. Arana, Temas centrales del diálogo ciencia-fe en la actualidad, "Scripta Theologica" 39 (2007,), s. 479-494; J. I. Murillo, żSon realmente autónomas las ciencias?, w: J. Aranguren (red.), Fe y razón. I Simposio Internacional sobre Fe Cristiana y Cultura Contemporánea, Pamplona 1999, s. 473-480; G. Colzani, Scienza e fede. Teologia della natura e teologia della creazione, "Path" 9 (2010), s. 301-323. 
rozum sobie nakłada, gdy redukuje się do tego, co można zweryfikować przez doświadczenie, i ponownie mu otworzymy horyzonty w całej ich rozciągłości" ${ }^{20}$.

To poznanie mądrościowe nie jest poznaniem niepewnym. Jeśli by tak było, cała ludzkość, włączając w to największych myślicieli starożytności, średniowiecza i współczesności, żyła w irracjonalności. Potrzebna jest racjonalność metafizyczna, która podejmie refleksję nad pytaniami, na które metoda empiryczna nie może odpowiedzieć na drodze doświadczenia. Ta refleksja metafizyczna ze swej strony nie może ignorować swoich ograniczeń w udzielaniu odpowiedzi skończonych, i powinna otworzyć się na racjonalność teologiczną, to znaczy, być skłonną do rozważania sensu i celu egzystencji, które nie pochodzą ze świata, lecz od Boga ${ }^{21}$. Byłoby irracjonalnym zamknięcie się, przynajmniej na poziomie hipotezy, na odpowiedź religijną o znaczeniu człowieka i jego przeznaczenia, która nie jest możliwa do wydedukowania z prostego poznania ludzkiego, choć z nim się wiąże.

Kiedy przesąd "scjentystyczny” neguje możliwość osiągnięcia pewności poza tym, co empirycznie weryfikowalne, dochodzi się w konsekwencji do praktycznego przekonania, że zagadnienia dotyczące znaczeniu i celu życia ludzkiego należą do drugorzędnych kwestii ${ }^{22}$. Tym bardziej nawet, że określanie prawd absolutnych w tej przestrzeni niosłoby z sobą ryzyko narzucania ich również w sposób absolutny, wraz ze związanym z tym niebezpieczeństwem dla pluralizmu i tolerancji. Jednak jest oczywiste, że wszyscy ludzie opierają swoje życie na tych czy innych prawdach i pewnościach. Istnieją prawdy, które narzucają się w sposób absolutny w obszarze fizyki (prawo ciążenia) czy w moralno-

${ }^{20}$ Discurso, 12 IX 2006, n. 15.

${ }^{21}$ D. L. Schindler, Overcoming the separation between faith and reason: the circular relation of philosophy and theology and its implications for the relational structure of (philosophical) knowledge, w: J. Prades, J. Ma. Magaz (red.), La Razón Creyente. Actas del Congreso Internacional sobre la Encíclica Fides et Ratio, Madrid 2002, s. 320-367; G. Cottier, Le rôle de la philosophie dans le dialogue entre la science et la foi, "Nova et Vetera" 79 (2004), s. 309-318.

${ }_{22}$ Por. J. Ratzinger, Glaube, Wahrheit und Kultur. Reflexionen im Anschluss an die Enzyklika Fides et Ratio, w: J. Prades, J. Mª. Magaz (red.), La Razón Creyente. Actas del Congreso Internacional sobre la Encíclica Fides et Ratio, Madrid 2002, s. 2-41; R. Fisichella, Verità, fede e ragione in J. Ratzinger, "Path" 6 (2007), s. 27-43; P. O'Callaghan, L'incontro tra fede e ragione nella ricerca della verità, w: G. Maspero, M. Pérez de Laborda, Fede e Ragione: l'incontro e il cammino. In occasione del decimo anniversario dell'enciclica Fides et Ratio, Siena 2011, s. 35-60. 
ści: na przykład sama idea tolerancji opiera się na absolutnej prawdzie o niezbywalnej godności osoby, z czego wynika, że narzucanie czegoś siłą byłoby sprzeczne $\mathrm{z}$ tą godnością.

Odzyskanie otwarcia rozumu na prawdę objawioną jest jednym z warunków niezbędnych dla ewangelizacji. Jeśli rozum zamyka się na tę możliwość, przyjęcie orędzia Ewangelii będzie uznawane za zwykłą subiektywną opcję daleką od racjonalności. W rzeczywistości zachodzi coś przeciwnego: zredukowanie tego, co racjonalne jedynie do tego, co weryfikowalne empirycznie to opcja woluntarystyczna racjonalnie nieuzasadniona, ponieważ jest nieracjonalne odrzucanie możliwości prawdy objawionej, jeśli istnieją ugruntowane znaki jej realizacji de facto w historii. Właśnie dlatego, że objawienie Boże jest godne wiary, poznanie, którego dostarcza, jest prawdziwe, a wiara racjonalna. Prawda wychodzi na spotkanie człowiekowi, a rozum ludzki poprzez wiarę może przyglnąć do tej prawdy i zakorzenić się w pewności moralnej, która czyni akt wiary racjonalnym. Nie chodzi o „udowadnianie” wiary przez ścisłe dowody, na zasadzie dowodów empirycznych. Chodzi natomiast o pokazanie racjonalnej prawomocności przyjęcia pewnych „motywów” dla aktu wiary ${ }^{23}$.

\subsection{UWOLNIĆ RACJONALNOŚĆ OD KWESTII SENSU}

Nie jest czymś rzadkim usłyszeć, że irracjonalność postmodernistyczna, w zgodzie z podtrzymującym ją ateizmem, sugeruje, że zagadnienie sensu samo jest pozbawione sensu. Skoro Bóg nie istnieje, to również nie ma wcześniejszej celowości danej w bycie rzeczy, ani nie ma miejsca na pytanie o obiektywny sens egzystencji, odmienny od tego,

${ }^{23}$ Por. tamże, s. 237-244. Por. także J. Alfaro, Problematica teologica attuale della fede, "Teologia" 6 (1981), s. 219-221; A. Novo, El asentimiento creyente: los motivos de la fe, w: J. Prades, J. Ma. Magaz (red.), La Razón Creyente. Actas del Congreso Internacional sobre la Encíclica Fides et Ratio, Madrid 2002, s. 526-538; R. Fisichella, La credibilità della rivelazione cristiana, "Lateranum" 73 (2007), s. 39-51; K. Kaucha, Arguments for the credibility of Christianity in Johns Paul II's Encyclical Fides et ratio, "Lateranum" 70 (2004), s. 475-487; G. De Rosa, É ragionevole credere?, "La Civiltà Cattolica" III (2005) 3721, s. 41-50; G. Lorizio, Le ragioni della fede, w: tenże, Fede e ragione. Due ali verso il Vero, Paoline, Milano 2003, s. 163-187; J. M Odero, Razonabilidad de la fe, w: tenże, Teología de la fe, Pamplona 1997, s. 155-176; M. A. Kopiec, Il fondamento della fede e la sua ragionevolezza. Un contributo al dibattito attuale, "Antonianum" 83 (2008), s. 419-450. Dla systematycznego wykładu wiarygodności objawienia, por. F. Ocáriz, A. Blanco, Revelación, Fe y Credibilidad, Palabra, Madrid 1998, s. 311-540. 
który jednostka chciałaby mu przypisać wedle swej woli. Bez Boga, świat i człowiek są niespokojnymi przypadkami, egzystencją zdezorientowaną, pozbawioną celowości.

Ale pytanie o sens pozostaje, pomimo deklaracji o jego nieznacznej wartości ${ }^{24}$. Pytania zostały postawione. Człowiek spotyka się z nimi choćby tylko z tej racji, że istnieje. Może odpowiedzieć w taki czy inny sposób, ale nie może tych pytań wyeliminować. Nihilizm indyferentny będzie musiał przyznać, że nie da się uniknąć pytań o dlaczego i po co egzystencji osobowej i świata, o celowości historii ludzkiej. Nawet w naukach naturalnych nadal trwają dyskusje nad determinizmem i indeterminizmem czy też o przypadku i celowości.

W rzeczywistości byt ludzki nie przyjmuje absurdu i szuka sensu rzeczy. Istnieje pierwotne zaufanie w racjonalność tego, co realne, pomimo tego, że nihilizm będzie mówił, że wydaje się, iż nic nie ma sensu. Pomimo przygodności ludzkiego bytu istnieje ogólne przekonanie, że jest czymś racjonalnym pokładać ufność, że rzeczy mają jakiś sens. Jednostka nie jest wyizolowana w przemijającym świecie, czystym factum bez kierunku. To przekonanie zakłada już w formie zaczątkowej wiarę w Kogoś, który daje rację (logos) dla tej nadziei. To instynktowne przekonanie, że początek i istnienie świata odwołują się do logosu-rozumu i nie do irracjonalnego przypadku.

Dlatego istnienie czy nieistnienie Boga nie jest obojętne. „Dochodząc do definitywnej kwestii, powiedziałbym - stwierdza Benedykt XVI - Bóg albie istnieje albo nie istnieje. Istnieją tylko te dwie opcje. Albo uznaje się pierwszeństwo rozumu, Rozumu stwarzającego, który jest u początku wszystkiego i jest zasadą wszystkiego [...] albo utrzymuje się pierwszego tego, co irracjonalne, wedle którego wszystko, co dzieje się na ziemi i w naszym życiu byłoby przypadkowe, marginalne, produktem irracjonalnym; rozum byłbym produktem irracjonalności"25.

Społeczeństwo zachodnie wydaje się mieć uśpionego ducha krytycznego, jakby brakowało życiowego impulsu, aby podjąć kwestie ostatecznego i przejść - przywołując słowa Jana Pawła II - „od fenomenu do fundamentu"26. Dlatego nowa ewangelizacja musi obudzić wrażliwość duchową i zdolność do refleksji nad zagadnieniem sensu. Również w tym

${ }^{24}$ Por. V. Sanz, La cuestión del sentido, lugar de encuentro de la fe y de la razón, w: J. Aranguren (red.), dz. cyt., s. 241-257.

${ }^{25}$ Encuentro del Santo padre con los jóvenes de Roma y del Lacio, 6 IV 2006.

${ }^{26}$ Enc. Fides et Ratio, n. 83. Por. J. Sánchez-Cańizares, dz. cyt., s. 862. 
punkcie trzeba będzie ocalić autentyczną racjonalność ludzką, ponieważ „pochodzenie tego, co racjonalne od tego, co irracjonalne, jest głęboko irracjonalne" 27.

Odzyskanie racjonalności pytania o znaczenie życia jest więc innym z założeń praeparatio evangelii, która przygotowuje do głoszenia wiary. Istotnie, „wtedy zwłaszcza, kiedy «przyczyna rzeczy» poddawana jest całościowym badaniom, poszukującym ostatecznej i wyczerpującej odpowiedzi, rozum ludzki dosięga swego szczytu i otwiera się przed religią. Religijność bowiem stanowi najwznioślejszy wyraz osoby ludzkiej, gdyż jest szczytem jego rozumnej natury"28.

Człowiek jest zdolny do wejścia w „związek” z Bogiem. A jest do tego zdolny, ponieważ jest konstytutywnie odniesiony do Boga i posiada „ukierunkowanie ontologiczne" na Niego. Bóg nie jest na peryferiach bytu ludzkiego, lecz stanowi centrum, które nadaje sens wszystkim wymiarom tego, co realne.

$* * *$

Ekspansja ateizmu i indyferentyzmu religijnego pokazuje, że zasadniczą misją chrześcijan jest pomóc wszystkim ludziom wierzyć w Boga Stworzyciela i Zbawcę w Jezusie Chrystusie. Zjawisko milczącej apostazji i laicyzmu we współczesnych społeczeństwach zachodnich unaocznia, że wśród wielu spraw, trzeba postawić w centrum odpowiedzialności ewangelizacyjnej inteligentną apologię, która przedłuży tę charakterystykę wiary chrześcijańskiej, którą jest tradycyjne pojednanie między wiarą a rozumem. W ten sposób nie tylko głoszenie Ewangelii będzie mogło wyjść naprzeciw trudnościom przeżywanym przez tak wielu współczesnych, lecz również sama wiara uleczy rozum z jego redukcjonizmów, jak to pokazał papież Jan Paweł II w encyklice Fides et ratio ${ }^{29}$.

Tłumaczenie z j. hiszpańskiego - ks. Piotr Roszak

27 Por. tamże, s. 866.

${ }^{28}$ Enc. Fides et Ratio, 14 IX 1998, przypis 28.

${ }^{29}$ Dobrym podsumowaniem historii realacji wiary i rozumu w tradycji chrześcijańskiej jest artykul: Ch. Morerod, Foi et raison dans la connaissance que nous avons de Dieu, "Nova et Vetera" 73 (1998), s. 113-137. Por. L. Rodríguez, La reivindicación de la razón humana en la encíclica Fides et Ratio, w: J. Prades, J. Ma. Magaz (red.), La Razón Creyente. Actas del Congreso Internacional sobre la Encíclica Fides et Ratio, Madrid 2002, s. 288-296. 
Streszczenie. Zadanie ewangelizacji musi brać pod uwagę położenie odbiorców przesłania. Obecnie na Zachodzie notuje się brak jednolitego kulturowego kręgosłupa, zdolnego podtrzymywać postawę religijną. Zatem kryzys wiary łączy się z rozwiązaniem pewnych preambuł, służących jako filary chrześcijańskiej wiary, pośród nich są: otwartość istoty ludzkiej na Boga, autentyczna racjonalność, możliwość uchwycenia prawd, prymat pojęć dobra i zła wobec zgody społecznej, znaczenie życia ludzkiego, oraz istnienie Boga. Odzyskanie tych preambuł wiary jest konieczne. Nowa ewangelizacja wymaga zatem preparatio evangelii, która jest świadoma tych kulturowych uwarunkowań.

Słowa kluczowe: wiara; preambuły wiary; nowa ewangelizacja.

Abstract. Praeparatio evangelica or preambles to faith in our time. The task of evangelization must take into consideration the circumstances of the message recipients. Currently, in the West there is a lack of a unitary cultural fibre capable of sustaining a religious attitude. Thus the crisis of faith is linked to the dissolution of certain preambles that used to serve as pillars of the Christian faith, among them: the openness of the human being to God; authentic rationality; the possibility of grasping truths; the primacy of the notions of good and evil over social consensus; the meaning of human life; and the existence of God. It is necessary to recover these preambles to faith. The new evangelization therefore requires a praeparatio evangelii which is mindful of these cultural circumstances.

Keywords: faith; preambles to faith; new evangelization. 